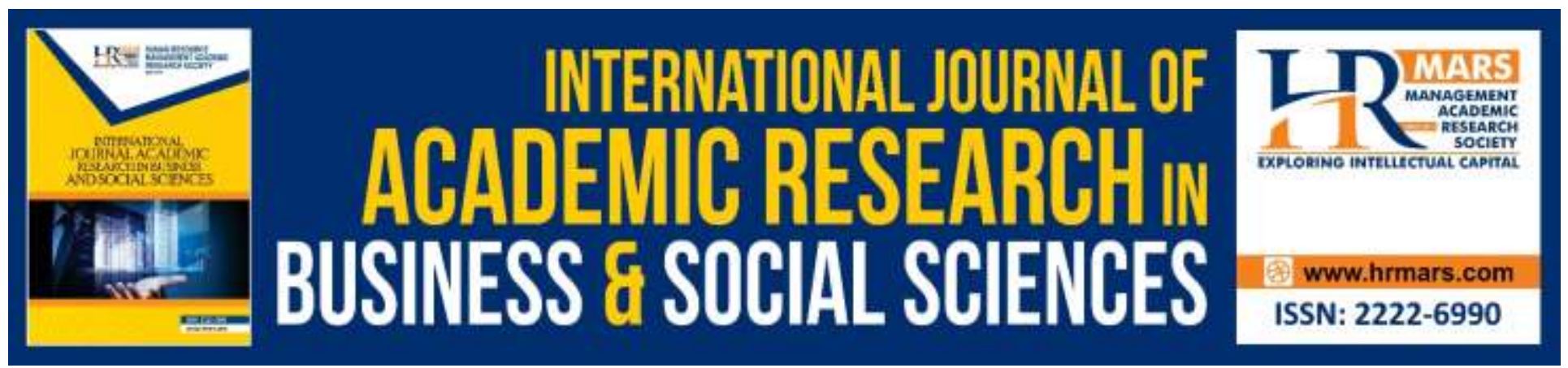

\title{
The Role of the Micro Finance System in the Issue of Youth Unemployment
}

\begin{abstract}
Zaihana Binti Manshor, Shuhairimi Bin Abdullah, Abu Bakar Bin Hamed, Norhasyikin Binti Rozali, Balqis Binti Yaacob @ Salleh
\end{abstract}

To Link this Article: http://dx.doi.org/10.6007/IJARBSS/v9-i6/6076

DOI: $10.6007 /$ IJARBSS/v9-i6/6076

Received: 20 April 2019, Revised: 19 May 2019, Accepted: 01 June 2019

Published Online: 25 June 2019

In-Text Citation: (Manshor, Abdullah, Hamed, Rozali, \& Salleh, 2019)

To Cite this Article: Manshor, Z., Abdullah, S. Bin, Hamed, A. B. Bin, Rozali, N. B., \& Salleh, B. B. Y. @. (2019). The Role of the Micro Finance System in the Issue of Youth Unemployment. International Journal of Academic Research in Business and Social Sciences, 9(6), 1147-1151.

Copyright: (c) 2019 The Author(s)

Published by Human Resource Management Academic Research Society (www.hrmars.com)

This article is published under the Creative Commons Attribution (CC BY 4.0) license. Anyone may reproduce, distribute, translate and create derivative works of this article (for both commercial and non-commercial purposes), subject to full attribution to the original publication and authors. The full terms of this license may be seen at: http://creativecommons.org/licences/by/4.0/legalcode

Vol. 9, No. 6, 2019, Pg. $1147-1151$

Full Terms \& Conditions of access and use can be found at http://hrmars.com/index.php/pages/detail/publication-ethics 


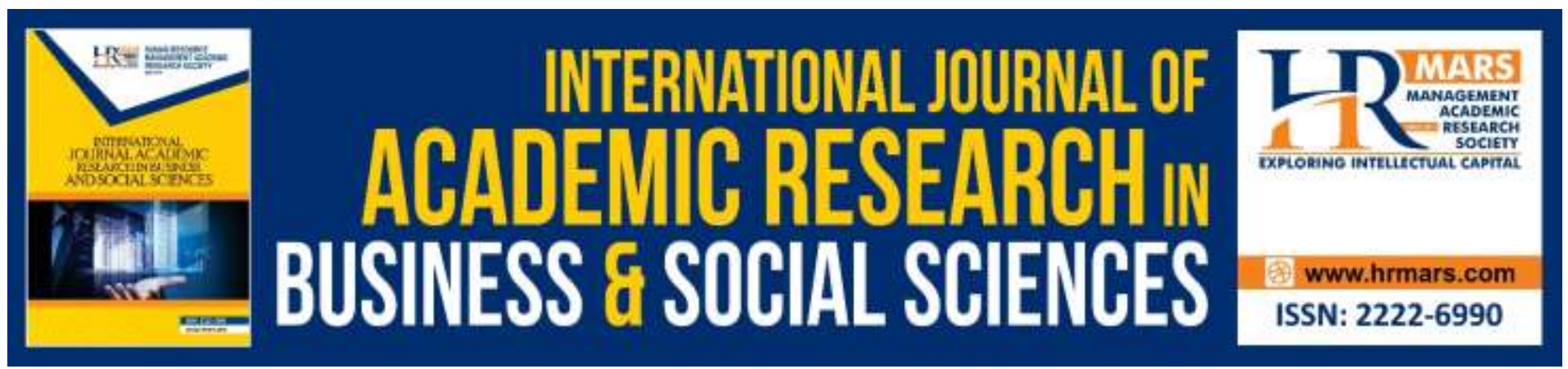

\title{
The Role of the Micro Finance System in the Issue of Youth Unemployment
}

\author{
Zaihana Binti Manshor, Shuhairimi Bin Abdullah, \\ Abu Bakar Bin Hamed, Norhasyikin Binti Rozali, Balqis Binti Yaacob \\ @ Salleh \\ Postgraduate Students \& Senior Lecture Universiti Malaysia Perlis, Senior Lecturer, Universiti Utara \\ Malaysia \\ Email: zaihanamans@yahoo.com
}

\begin{abstract}
The problem of youth unemployment, still remains an issue and challenge in the country. This unemployment issue is seen as severely because of the string of other social phenomena in society. Hence, microfinance is considered as the best mechanism in finding solutions to these problems. The objective of this study is to explore the extent to which microfinance is able to play a role in solving the problem of youth unemployment. In the meantime, the method used is through secondary data sources derived from online databases and library collections. In conclusion, through funds from microfinance the youths are able to get out of the unemployed cocoon by making capital to start up for business.
\end{abstract}

Keywords: Micro Finance System, Unemployment, Youth

\section{Introduction}

Today, the country is often surprised by the growing number of social problems. Various issues can be seen and heard through local social media. Criminal cases, vandalism, illegal smuggling, and so on are often filling in current news. Ironically, the increase in social phenomena is seen to be closely related to unemployment and poverty. Both of these issues are very synonymous and interconnected with each other. This is because unemployment will cause an individual to have no source of income and cannot meet the basic needs of his life. Over time it will lead to poverty. In fact, there are hadith said that poverty leads to disbelief. According to Hafid (2011), the disbelief is seen through the actions or conduct of an individual who tends to do bad things and violates religion other than not performing obligations and obeying His instructions. It is undeniable that an individual who lives in difficulty will feel desperate to meet needs and desires. Therefore, any action which may satisfy him will be possible even if it is a violation of the law. In a study conducted at detention centers in the East Coast of Peninsular Malaysia, the majority of juvenile trainers came from families earning RM500 and below 
and had a large number of family members (Bahrom, 2004). This proves that the hardship of life leads to unethical behavior. In the meantime, the cause of poverty which is a serious unemployment among society is now a contributing factor to the social phenomena of the country. Statistics show that the increase in the number of unemployed consists of various categories, especially youth. Although there are certain parties who argue that the unemployment problem in Malaysia is still low compared to other developing countries, it is up to us that this amount is increasing from time to time. It is not impossible that continuous improvement without effective solutions will have a bad impact on society and the country.

\section{Youth Unemployment}

According to the Labor Force Statistics of Malaysia (2018), the total number of unemployed in August for 2018 is 525,000 with an unemployment rate of 3.4\% and this is an increase from 2017 to 516,900. The $1.6 \%$ increase is drastic and relatively critical even in just one year. Furthermore, the more worrying is the level of unemployment in the country is much higher than other neighboring countries. According to Dr Anthony Dass, Chief Economist of Ambank Research, the percentage of unemployed among youth in Malaysia for 2018 is $10.8 \%$ while Singapore shows $4.6 \%$ and Thailand is $5.9 \%$. The differences of this statistic is important because there is a significant gap between neighboring countries. This situation is worst when Malaysia is the highest unemployment among youth in the Asian region besides Indonesia (Razaleigh, 2014). In addition, this high level of youth unemployment will bring many problems in the future. According to Steven (2014), there are unemployment studies conducted in the United States and the United Kingdom that have shown that youth unemployment in the early 20's would have a bad impact on the quality of their jobs over the next ten years, up to the age of 30s. There is a proverb saying that youth today is the next generation leader. It is undeniable that the future of a country will depend on the present young people. The goals and aspirations of youths can determine the progress or decline of society and the overall aspects of the country.

\section{Microfinance System}

Growth in the economic sector has contributed to the development of the microfinance industry in Malaysia. After almost 30 years of this system operates, various social problems such as poverty and unemployment have been dumped. Generally, this microfinance system has been around for some time around 1970. As a pioneer in this system, Professor Muhammad Yunus has succeeded in establishing a Grameen Bank that plays a huge role for Bangladeshis. His brilliant ideas have contributed to the improvement of the lives of the poor who were often oppressed. After decades, the micro-finance system has become more popular and has been implemented in other countries such as Sudan, Nigeria and many more. These microfinance-oriented institutions have also been established around the world. Indirectly, this microfinance system becomes the ultimate solution in combating world poverty (Leikem, 2012). In Malaysia, this microfinance system started its foundation in early 1986 through the establishment of Amanah Ikhtiar Malaysia (AIM). Subsequently, the establishment of the Tabung Ekonomi Kumpulan Usahawan Nasional (TEKUN), cooperatives and other institutions also boosted the microfinance industry in Malaysia (Faizal, 2012). Based on each such institution, there are a variety of financing products offered to customers according to a 
particular classification. Thus, this division of classification can focus on target groups. For example, youths, single mothers and so on. According to Ekpe (2011), microfinance is the provision of credit, savings and training for business success and increased entrepreneurial welfare. This shows that the aid channel is not just financial, but training is provided to help target income-generating groups.

\section{The Role of Microfinance System on the Unemployment Issue}

Various initiatives and incentives have been allocated to help youths to increase their economy's aspect. Efforts from government and non-governmental organizations have been implemented in various ways. One of these is the microfinance system, which is wider in the country. For those who are new to entrepreneurship, microfinance is the best option as a starting point for startup a business. Today, youths are encouraged to engage in entrepreneurship. This field is seen as a potential field in building youth careers. Young people should not rely only on existing employment opportunities. They need to be more independent and creative in finding income sources. By involving in entrepreneurship, youths are no longer dependent on existing job opportunities either in the government or private sectors. In addition, they also can be an inventors of new job opportunities for other individuals. However, the unemployment problem amongst these youths remains a critical problem in society. Although various efforts have been carried out by many parties. As we know, the microfinance system is growing rapidly in the country, but the problem of unemployment among youth is not as good as possible. The establishment of many microfinance institution should encourage the presence of new entrepreneurs. Additionally, graduates should be wiser to obtain information and deserve the opportunity. Hence, the effectiveness of the role of the microfinance system should be empowered by each party to address the issue of youth unemployment in society today.

\section{Conclusion}

In the nut shell, microfinance is a tool that can play a role in promoting youth economics by enabling them to engage in entrepreneurship. In addition, it is also considered the best platform in solving various social problems indirectly. This is because the unemployment problem is closely related to social issues among the community. In the meantime, the establishment of microfinance-oriented institutions such as Amanah Ikhtiar Malaysia (AIM), TEKUN and cooperatives should be further enhanced, in addition to improving management and expose more to the community. The close collaboration with the bank for example can further strengthen the functions of these institutions.

\section{Corresponding Author}

Zaihana Manshor, Postgraduate Students, School of Human Development and

Techocommunication (iKOM), Pusat Pengajian Unimap, Perlis.

Email: zaihanamans@yahoo.com

\section{References}

Alshebami, A. S. (2014). Microfinance in Yemen "Challenges and Opportunities". International Journal in Management and Social Science, 400-413. 
INTERNATIONAL JOURNAL OF ACADEMIC RESEARCH IN BUSINESS AND SOCIAL SCIENCES

Vol. 9, No. 6, June, 2019, E-ISSN: 2222-6990 (C) 2019 HRMARS

Basaruddin, N. (2018, September 18). Pengangguran Belia Tinggi Kekal Cabaran Utama. Retrieved from BH Online: https://www.bharian.com.my/bisnes/lainlain/2018/09/475197/pengangguran-belia-tinggi-kekal-cabaran-utama

Chowdury, A. (2009). Microfinance as a Poverty Reduction Tool- A Critical Assesment. DESA Working Paper, 1-13.

Dauda, R. O. (2014). Microfinance, Poverty and Employment Gender Gap: An Analysis from Nigerian Prospective. Semantic Scholar, 1-34.

Ekpe, I. (2011). Women Entrepreneurs' Performance : Microfinance Factors With Mediating Effect of Opportunity and Moderating Effect of Attitude. Sintok: UUM ETD.

Keong, S. S. (2015, May 15). Young Malaysians are Poor, Jobless and yet Taxed. Retrieved from Malaysiakini: https://www.malaysiakini.com/letters/298477

Leikim, K. (2012). "Microfinance: A Tool for Poverty Reduction?". kirsten leikem, 5-8.

Olu, O. (2009). Impact of Microfinance on Entrepreneurial Development: The Case of Nigeria. The International Conference on Administration and Business, 538-544.

Shaarani, A. F. (2012). Pembiayaan Mikro Mentranformasi Ekonomi Rakyat. Dimensi Koop, 57-61. 